\title{
STUDI PENGARUH GAYA TEKAN TERHADAP KARAKTERISTIK BIOBRIKET KULIT KAKAO (Theabroma cocoa L.)
}

\author{
Sandra, Bambang Susilo, dan Retno Damayanti \\ Jurusan Keteknikan Pertanian Fakultas Teknologi Pertanian Universitas Brawijaya \\ Jl. Veteran - Malang \\ Email: sandra.malinsutan@yahoo.co.id
}

\begin{abstract}
ABSTRAK
Limbah buah kakao yang dihasilkan berupa kulit kakao yang bekum bisa termanfaatkan denga baik. Pengolahan kulit buah kakao yang kurang tepat seperti didiankan dalam waktu yang lama akan menimbulkan masalah baru untuk lingkungan yaitu pembusukan Karen adanya penguraian karbon oleh mikroorganisme. Solusi penanganan limbah kulit kakao adalah dnegna menjadikannya sebagai biobriket. Biobriket kulit kakao dapat dibuat karena berbahan keras dan $90 \%$ mengandung bahan kering. Pembuatan kulit kakao menjadi briket sangat mudah dengan empat tahapan yaitu pengeringan bahan, penggerusan, pencampuran dengan perekat dan pencetakan menjadi biobriket. Biobriket yang dihasilkan ini dapat digunakan sebagai energi alternatif menggantikan kayu bakar atau LPG untuk memasak. Tujuan dari penelitian ini adalah untuk mengetahui pengaruh gaya teka terhadap karakteristik biobriket kulit kakao sebagai salah satu bahan bakar alternatif. Metode yang digunakan dalam penelitian ini adalah metode eksperimen dengan 3 perlakuan yaitu gaya tekan $100 \mathrm{~kg}, 150 \mathrm{~kg}$, dan 200 pada masing-masing perlakuan dilakukan 3 kali pengulangan. Pada masing-masing gaya tekan berat adonan yang akan dicetak yaitu $0,5 \mathrm{~kg}$. Biobriket mempunyai ukuran diameter dalam $10,7 \mathrm{~cm}$ tinggi $10 \mathrm{~cm}$ dengan jari-jari tengah pada pengempa dengan diameter dalam 1,9 cm. Karakterisasi biobriket kulit kakao meliputi pengujian kadar air, kadar abu, kadar karbon, densitas, laju pembakaran briket, nilai kalor dan efisiensi pembakaran biobriket. Dari penelitian diperoleh data kadar air briket setelah dikeringkan selama 24 jam, briket dengan gaya tekan $100 \mathrm{~kg}$, $150 \mathrm{~kg}$ dan $200 \mathrm{~kg}$ kadar airnya adalah $14,607 \%, 14,232 \%$ dan 13,834 \%. Gaya tekan tidak berpengaruh terhadap kadar abu briket dan kadar karbon, yang masing-masing bernilai $27,89 \%$ dan $60,55 \%$. Densitas briket kulit kakao yang dihasilkan pada gaya tekan $100 \mathrm{~kg}, 150 \mathrm{~kg}$ dan $200 \mathrm{~kg}$ masing-masing yaitu $0,96 \mathrm{~kg} / \mathrm{cm}^{3}, 0,99 \mathrm{~kg} / \mathrm{cm}^{3}$, dan 1,04 $\mathrm{kg} / \mathrm{cm}^{3}$. Laju pembakaran terbesar adalah pada briket dengan gaya tekan $200 \mathrm{~kg}$, sebesar $6 \mathrm{~g} / \mathrm{menit}$. Semakin besar laju pembakaran maka akan mempercepat waktu briket habis terbakar. Biobriket gaya tekan $200 \mathrm{~kg}$ memiliki kadar air yang rendah dan nilai kalor tertinggi sehingga briket cepat habis terbakar. Pada briket gaya tekan $150 \mathrm{~kg}$ memiliki laju pembakaran rendah dari yang lain karena pada gaya tekan tersebut terdapat batas kekuatan maksimal pada butiran. Gaya tekan berpengaruh terhadap nilai kalori pada briket, semakin tinggi gaya tekan nilai kalori semakin meningkat. Densitas $0,96 \mathrm{~kg} / \mathrm{cm}^{3}$ menghasilkan nilai kalori 4187,11 kal/g, densitas 1,044 kg/ $\mathrm{cm}^{3}$ menghasilkan nilai kalori 4509,30 kal/g. Perlakuan gaya tekan dapat memperlihatkan kelebihan pada briket yang diberikan gaya tekan adapun kelebihan briket diberi gaya tekan berbeda diantaranya dapat meningkatkan densitas, nilai kalori briket, menurunkan kadar air.
\end{abstract}

Kata kunci-biobriket; gaya tekan; kulit kakao

\section{PENDAHULUAN}

Indonesia merupakan salah satu negara penghasil kakao terbesar ketiga di dunia. Produksi kakao atau coklat di Indonesia mengalami pertumbuan yang signifikan mencapai 3.5\% setiap tahunnya. Tingkat produksi buah kakao yang tinggi berbanding lurus dengan meningkatnya limbah kulit kakao. Berat kulit buah kakao mencapai $75 \%$ seluruh berat buah sehingga dapat dikatanan bahwa limbah utama pengolahan buah kakao adalah kulit (cangkangnya). Hal ini memberikan dampak negatif karena pemanfaatannya hanya $25 \%$ dari buah kakao yaitu biji kakao, sedangkan $75 \%$ merupakan kulit kakao (Ashadi, 1998).

Kulit kakao merupakan limbah dari buah kakao yang dapat ditemukan di perkebunan besar atau agroindustry yang saat ini kebayakan dimanfaatkan sebagai pakan ternak maupun pupuk tanaman dengan cara ditimbun di sela-sela tanaman kakao. Pemanfaatan limbah kulit kakao sebagai pupuk tanaman dilakukan karena kandungan unsur hara dan mineral yang cukup tinggi pada kulit buah kakao 
seperti Nitrogen dan Kalium. Sedangkan pemanfaatan kulit kakao untuk pakan ternak karena kandungan lemak, asam organik, kandungan kadar serat yang tinggi, protein rendah, mengandung alkaloid theobromin serta asam fitat (Isroi, 2007). Limbah kulit kakao yang tidak ditangani secara serius memiliki potensi untuk menimbulkan masalah lingkungan dan kesehatan masyarakat. Limbah kulit kakao akan memiliki peranan yang cukup berarti dan berpotensi jika dijadikan sebagai energi alternatif.

Bentuk penanganan limbah kakao (biomassa) sebagai energi alternatif dengan menjadikannya biobriket. Pembriketan biomassa adalah proses penggumpalan butiran-butiran kecil dengan atau tanpa bahan perekat dalam bentuk, ukuran serta sifat-sifat tertentu yang bertujuan untuk meningkatkan mutu dan daya guna biomassa sehingga tidak berasap dan berbau, juga mudah dipakai (Rustina, 1987). Kulit buah kakao memiliki kandungan selulosa atau serat kasar. Serat ini bisanya menjadi syarat pembuatan briket (Brades dan Febrina, 2008).

Proses pembriketan dimulai dengan pengarangan, penggilingan arang, pencampuran dengan bahan perekat, pencetakan adonan, dan pengeringan briket. Faktor-faktor yang mempengaruhi sifat briket arang adalah berat jenis bahan bakar atau berat jenis serbuk arang, kehalusan serbuk, suhu karbonisasi, dan tekanan pengempaan (Kurniawan dan Marsono, 2008). Proses densifikasi merupakan salah satu cara untuk memperbaiki sifat fisik suatu bahan dengan tujuan untuk mempermudah penggunaan dan pemanfatannya, sehingga dapat meingkatkan efisiensi bahan yang digunakan (Abdullah et al., 1998).

Proses densifikasi atau pengempaan menjadi cara untuk peningkatan kualitas biomassa sebagai sumber energi. Pengempaan yang dilakukan menggunakan alat kempa hidrolik. Mutu briket yang akan dihasilkan mesin hidrolik jauh lebih baik dan lebih disukai oleh konsumen karena daya bakarnya awet. Cara mencetak briket hidrolik pada dasarnya tidak berbeda dengan metode manual. Adonan yang sudah siap dimasukkan ke lubang cetakan sampai terisi penuh, selanjutnya dongkrak hidrolik yang ujungnya dipasang sudu-sudu pengepres lalu mulai dikempa. Kempa akan bergerak ke bawah menuju cetakan. Bersama dengan itu adonan memadat, setelah padat adonan yang telah dicetak dikeluarkan lalu dikeringkan (Kurniawan dan Marsono, 2008). Gaya tekan pada briket akan berpengaruh terhadap karakteriksik briket. Sehingga penelitian ini bertujuan untuk mengetahui pengaruh gaya tekan terhadap karakteristik briket, laju pembakaran dan nilai kalor yang dihasilkan.

\section{METODOLOGI PENELITIAN}

\section{A. Bahan dan Alat}

Bahan-bahan yang digunakan adalah kulit kakao segar $18,4 \mathrm{~kg}$, tepung kanji sebanyak $0,32 \mathrm{~kg}$ dan air sebanyak 1 liter. Bahan tersebut untuk menghasilkan briket sebanyak 9 briket dengan masingmasing berat adonan $0,5 \mathrm{~kg}$. Pada perhitungan efisiensi bahan bakar briket, air yang digunakan sebanyak 18 liter.

Alat yang digunakan adalah drum bekas ukuran sedang, seng, alat kempa hidrolik Ton Shop Press 20 ton, yang telah dilengkapi dengan manometer, ayakan yang berukuran 60 mesh, oven, timbangan digital, cawan alumunium, eksikator, stopwatch, thermometer, alat cetak berbentuk silinder yang terbuat dari besi dengan diameter dalam $10,7 \mathrm{~cm}$ tinggi $10 \mathrm{~cm}$ dengan jari-jari tengah pada pengempa dengan diameter dalam 1,9 cm, mur, baut, mesin bubut, mesin gerinda potong, mesin las, kikir, bor, kompor, sendok, baskom, bomb kalorimeter, reaktor, kawat niklin, dan alat pendukung lainnya.

\section{B. Prosedur Percobaan}

Metode yang digunakan dalam penelitian ini adalah metode eksperimen dengan 3 perlakuan yaitu gaya tekan $100 \mathrm{~kg}, 150 \mathrm{~kg}$, dan 200 pada masing-masing perlakuan dilakukan 3 kali pengulangan. Pada masing-masing gaya tekan berat adonan yang akan dicetak yaitu $0,5 \mathrm{~kg}$. Flowchart pembuatan briket sebelum dikeringkan sampai dengan sesudah dikeringkan dengan hasil 9 briket disajikan pada Gambar 1. 

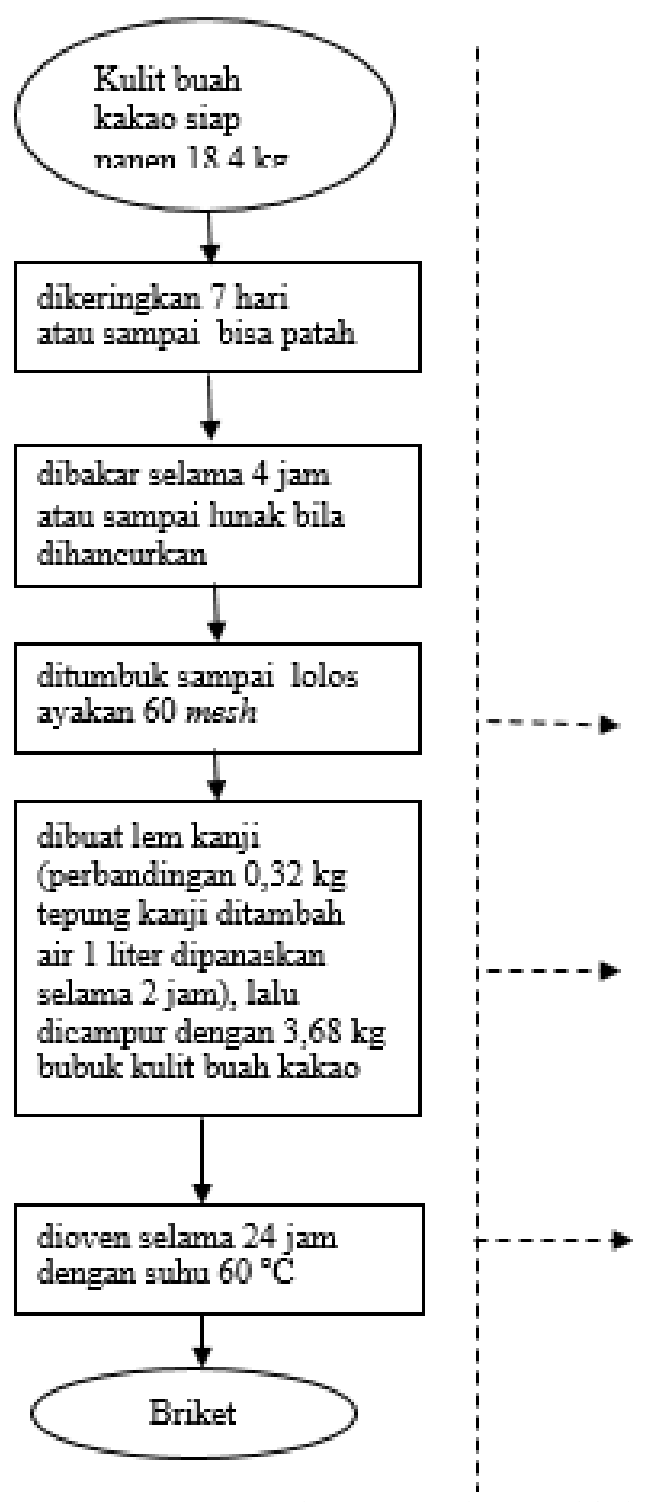

Bubuk kulit buah

kakao $3,68 \mathrm{~kg}$.

dilakukan pengukuran

densitas dan air (wb), kapasitas

alat.

dilakukan pengukuran efígiensi

bahan bakcar,laju pembakaran,

kadar air (wb), kadar air (db),

KKA, Setelah itu briket difivnace

untuk menentukan kadar abu, kadar

karbon, dan dilakukan pengukuran |

nilai kalor

Gambar 1. Pembuatan biobriket kulit kakao

Karakterisasi biobriket kulit kakao meliputi pengujian kadar air, kadar abu, kadar karbon, densitas, laju pembakaran briket, nilai kalor dan efisiensi pembakaran biobriket. Pengujian karakteristik biobriket mengacu pada standar mutu briket beberapa Negara.

Tabel 1. Standar mutu briket Negara Jepang, Inggris, Amerika dan Indonesia

\begin{tabular}{lcccc}
\hline Sifat Briket Arang & Jepang & Inggris & Amerika & Indonesia \\
\hline Kandungan air (\%) & $6-8$ & 3.6 & 6.2 & 8 \\
Kadar zat menguap (\%) & $15-30$ & 16.4 & $19-24$ & 15 \\
Kadar abu (\%) & $3-6$ & 5.9 & 8.3 & 8 \\
Kadar karbon terikat $(\%)$ & $60-80$ & 75.3 & 60 & 77 \\
Kerapatan (g/cm $\left.{ }^{3}\right)$ & $1-1.2$ & 0.46 & 1 & - \\
Keteguhan tekan $\left(\mathrm{kg} / \mathrm{cm}^{2}\right)$ & $60-65$ & 12.7 & 62 & - \\
Nilai kalor $(\mathrm{cal} / \mathrm{g})$ & $6000-7000$ & 7289 & 6230 & 5000 \\
\hline
\end{tabular}

Sumber: Hendra (2000) 
Tabel 2. Mutu briket berdasarkan Standar Nasional Indonesia (SNI)

\begin{tabular}{lc}
\hline Parameter & $\begin{array}{c}\text { Satndar Mutu Briket Arang Kayu } \\
\text { (SNI No. 01-6235-2000) }\end{array}$ \\
\hline Kadar air (\%) & $\leq 8$ \\
Kadar abu (\%) & $\leq 8$ \\
Bagian yang hilang pada pemanasan $950^{\circ} \mathrm{C}(\%)$ & $\leq 15$ \\
Nilai kalor (cal/g) & $\geq 5000$ \\
\hline
\end{tabular}

Sumber: Pusat Penelitian dan Pengembangan Hasil Hutan, 2000

\section{HASIL DAN PEMBAHASAN}

\section{A. Kadar Air Briket}

Bahan adonan briket adalah campuran dari lem kanji dan tepung bubuk kulit buah kakao. Kadar air diukur mulai dari adonan, adonan setelah dikempa atau dicetak dan setelah dikeringkan. Pada bahan bakar padat kandungan air terdapat dua macam yaitu sebagai air bebas (free water) yang mengisi rongga pori-pori didalam bahan bakar dan sebagai air terikat (bound water) yang terdapat pada dinding sel bahan bahar (Syamsiro dan Harwin, 2007).

Tabel 3. Kadar Air briket setelah dikempa

\begin{tabular}{lccc}
\hline \multicolumn{1}{c}{ Gaya tekan $(\mathbf{k g})$} & $\mathbf{1 0 0}$ & $\mathbf{1 5 0}$ & $\mathbf{2 0 0}$ \\
\hline Kadar air adonan setelah dikempa (\%) & 34,98 & 33,033 & 32,786 \\
Kadar air briket setelah dikeringkan $(\%)$ & 14,607 & 14,232 & 13,834 \\
\hline
\end{tabular}

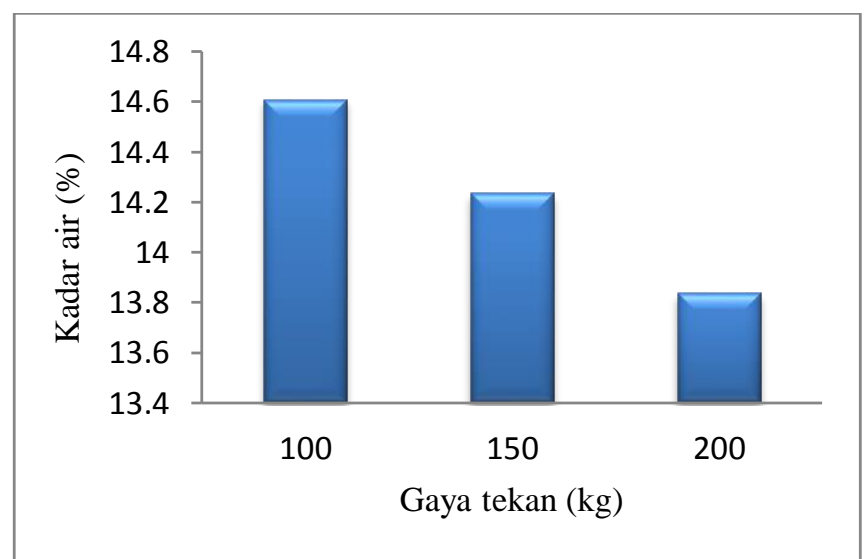

Gambar 2. Pengaruh gaya tekan terhadap kadar air biobriket

Kadar air adonan setelah dikempa pada gaya tekan $100 \mathrm{~kg}, 150 \mathrm{~kg}$ dan $200 \mathrm{~kg}$ yaitu 34,980 \%, $33.033 \%, 32,786 \%$. Kadar air pada briket mengalami penurunan karena tingginya tekanan yang diberikan, sehingga free water yang terdapat dalam rongga sel briket keluar melalui pori-pori dan berada di permukaan selanjutnya air akan menguap saat dikeringkan bersamaan dengan menguapnya bound water atau air yang terdapat pada dinding sel briket. Begitu juga dengan kadar air yang diukur setelah dioven selama 24 jam dengan suhu $60^{\circ} \mathrm{C}$ gaya tekan tertinggi mempunyai kadar air terendah. Masingmasing gaya tekan $100 \mathrm{~kg}, 150 \mathrm{~kg}$, dan $200 \mathrm{~kg}$ memiliki kadar air 14,607 \%, 14,232 \%, dan 13,834 \%. Kadar air briket kulit buah kakao dengan karbonisasi berkisar 13,834 \% - 14,607 \% lebih rendah dibandingkan dengan briket lain seperti cangkang kakao tanpa karbonisasi yaitu 16,1\% (Syamsiro dan Harwin, 2007). Kadar air briket kulit buah kakao tidak berbeda jauh dari briket batubara sekitar 14, 31\% (Balia, 2005), jika dibandingkan dengan briket cangkang kakao tanpa karbonisasi maka kadar air briket kulit buah kakao dengan karbonisasi cukup rendah. Kadar air yang dihasilkan masih cukup tinggi dikarenakan waktu pengeringan yang kurang lama dan suhu pengeringan yang digunakan terlalu rendah. Hal ini akan mengakibatkan nilai kalor yang rendah pada biobriket. 
Pada gaya tekan terendah air bebas (free water) pada briket tetap berada dibagian dalam sel briket dan air terikat (bound water) yang ada pada dinding sel briket mengalami sedikit penguapan sehingga menghasilkan kadar air tinggi, sedangkan gaya tekan $200 \mathrm{~kg}$ memiliki kadar air terendah karena air bebas yang terdapat pada bagian dalam briket keluar saat pengempaan sehingga akan mengurangi kadar air yang terdapat didalam briket.

\section{B. Densitas Briket Sebelum Dikeringkan}

Densitas briket dipengaruhi oleh gaya tekan, dengan massa yang sama namun gaya tekan yang berbeda maka akan menghasilkan densitas yang berbeda. Pada pengukuran kadar air telah disebutkan bahwa keadaan adonan saat diberikan gaya tekan $150 \mathrm{~kg}$ masih dalam keadaan cukup mampat sedangkan melebihi dari $150 \mathrm{~kg}$ atau $200 \mathrm{~kg}$ keadaan adonan briket sudah mampat sehingga menghasilkan kerapatan yang tinggi. Densitas briket yang dihasilkan pada gaya tekan $100 \mathrm{~kg}, 150 \mathrm{~kg}$, dan $200 \mathrm{~kg}$ masing-masing yaitu $0,96 \mathrm{~kg} / \mathrm{cm}^{3}, 0,99 \mathrm{~kg} / \mathrm{cm}^{3}$ dan $1,04 \mathrm{~kg} / \mathrm{cm}^{3}$. Semakin besar gaya tekan yang diberikan maka densitas biobriket kulit kakao semakin besar. Nilai densitas briket sesuai dengan standar mutu Amerika, Jepang, Inggris dan Indonesia (Tabel 1). Kerapatan akan memberikan pengaruh terhadap nilai kalor suatu bahan, kerapatan yang tinggi cenderung memberi nilai kalor yang tinggi dibandingkan yang berkerapatan rendah (Soeparno, 1992).

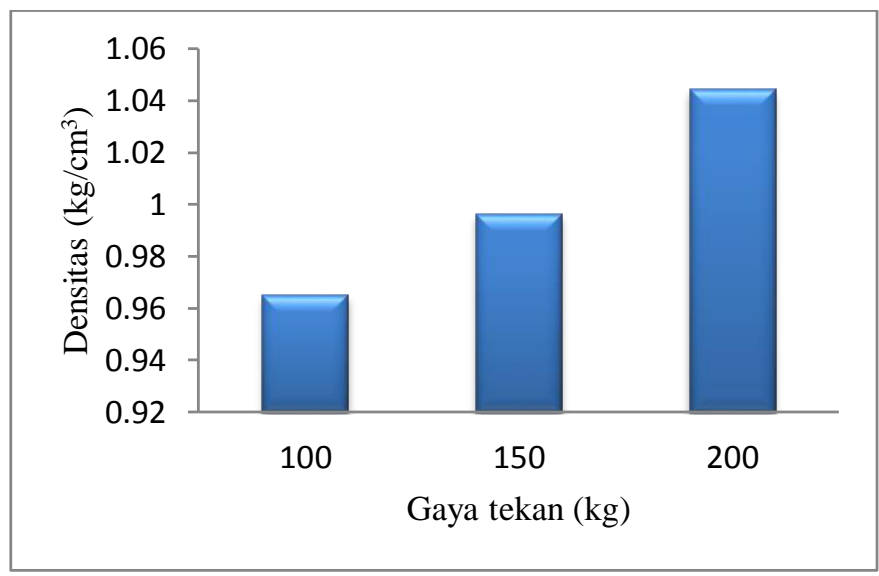

Gambar 4. Pengaruh gaya tekan terhadap densitas briket sebelum dikeringkan

\section{Kadar Abu Briket}

Abu merupakan bagian yang tersisa dari proses pembakaran yang sudah tidak meiliki unsur karbon lagi. Usur utama abu adalah silica dan pengaruhnya kurang baik terhadap nilai kalor yang dihasilkan. Semakin tinggi kadar abu maka semakin rendah kualitas biobriket karena kandungan abu yang tinggi dapat menurunkan nilai kalor (Muzakir et al., 2017). Metode pengujian kadar abu dilakukan dengan menetapkan persentase sisa hasil oksidasi kering benda uji pada suhu $\pm 580-600{ }^{\circ} \mathrm{C}$. Hasil penelitian menunjukkan variasi gaya tekan tidak berpengaruh terhadap kadar abu biobriket karena adanya perbandingan bahan baku dengan perekat yang sama. Kadar abu pada briket kulit buah kakao yang diperoleh yaitu $27,89 \%$. Kadar abu yang dihasilkan lebih tinggi dibandingkan penelitian Syamsiro dan Harwin (2007), dimana kadar abu briket kulit buah kakao dengan karbonisasi berkisar 27,89 \%, sedangkan tanpa karbonisasi 13,5 \%, pada penelitian batubara kadar abunya 2,02 \% (Balia, 2005), jerami 18,48 \% (Subroto dan Sartono, 2007) dan sekam 17,71 \% (Badan Penelitian dan Pengambangan Pascapanen Pertanian, 2008).

Keberadaan abu pada briket sangat tidak diinginkan karena dapat menimbulkan kerak pada tungku pembakaran dan juga dapat menurunkan nilai kalor pembakaran karena abu tidak memiliki unsur karbon dan nilai kalor lagi. Selain konsentrasi perekat, kadar abu briket juga dipengaruhi faktor jenis bahan yang digunakan. Pembuatan briket dengan menggunakan bahan baku yang memiliki kandungan silika yang tinggi, dapat menghasilkan kadar abu yang tinggi (Meyer dan Keeping, 2000). 


\section{Kadar Karbon terikat}

Kadar terikat yaitu fraksi karbon yang terikat dalam arang selain fraksi air, zat menguap dan abu. Keberadaan karbon terikat didalam biobriket arang dipengaruhi oleh niai kadar abu dan kadar zat terbang. Kadar karbon terikat akan bernilai tinggi apabila kadar abu dan kadar zat terbang rendah. Karbon terikat berpengaruh terhadap nilai kalor bakar biobriket arang. Nilai kalor biobriket akan tinggi apabila nilai nilai karbonnya tinggi. Masturin (2002) menjelaskan bahwa semakin tinggi kadar karbon terikat pada arang kayu maka arang tersebut adalah arang yang baik.

Variasi gaya tekan tidak berpengaruh terhadap kadar karbon pada briket. Kadar karbon biobriket kulit buah kakao yang dihasilkan adalah 60,55\%. Hasil peelitian masih sesuai dengan standar briket Negara Jepang, Inggris, Amerika dan SNI yaitu 60-80\% Kadar karbon kulit buah kakao dengan karbonisasi 60,55 \% batubara 69,53 \% (Balia, 2005), jerami 2,71 \% (Subroto dan Sartono, 2007) dan sekam 1,33 \% (Badan Penelitian dan Pengembangan Pascapanen Pertanian, 2008).

\section{E. Laju Pembakaran briket}

Laju pembakaran briket adalah kecepatan briket habis sampai menjadi abu dengan berat tertentu. Gaya tekan briket akan mempengaruhi kecepatan briket habis saat terbakar. Laju pembakaran diambil dari lamanya briket habis dan dilihat suhu yang terjadi pada briket.

Tabel 4. Laju Pembakaran Briket

\begin{tabular}{cccc}
\hline $\begin{array}{c}\text { Gaya tekan } \\
(\mathrm{kg})\end{array}$ & $\begin{array}{c}\text { Massa briket } \\
(\mathrm{g})\end{array}$ & $\begin{array}{c}\text { Waktu pembakaran } \\
(\text { menit})\end{array}$ & $\begin{array}{c}\text { Laju pembakaran } \\
(\mathrm{g} / \text { menit })\end{array}$ \\
\hline 100 & 600 & 130 & 4,615 \\
150 & 600 & 160 & 3,75 \\
200 & 600 & 100 & 6 \\
\hline
\end{tabular}

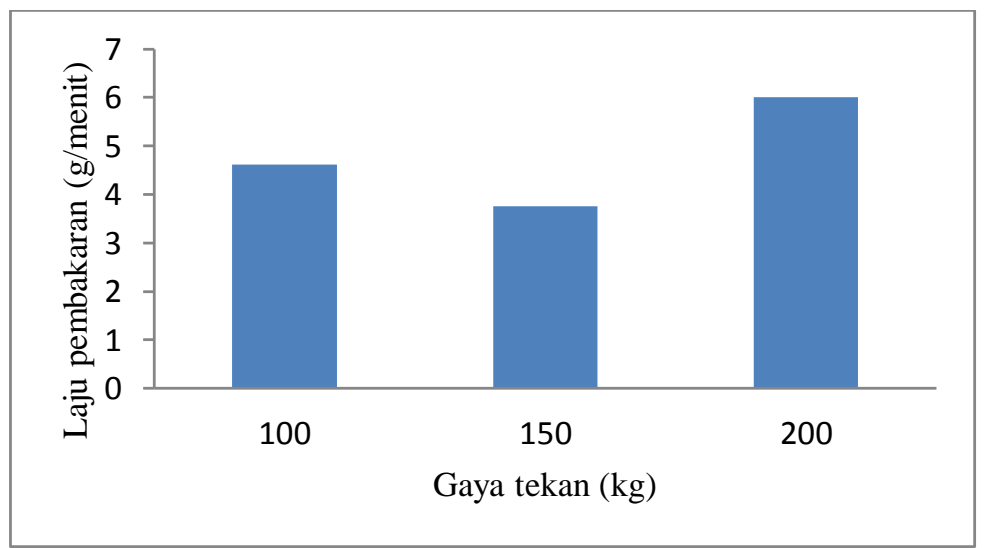

Gambar 5. Pengaruh gaya tekan terhadap laju pembakaran briket

Laju pembakaran briket pada gaya tekan $100 \mathrm{~kg}, 150 \mathrm{~kg}$ dan $200 \mathrm{~kg}$ yaitu 4,61 g/menit, 3,75 $\mathrm{g} /$ menit dan $6 \mathrm{~g} /$ menit. Laju pembakaran terbesar adalah pada briket dengan gaya tekan $200 \mathrm{~kg}$ dengan laju pembakarannya $6 \mathrm{~g} / \mathrm{menit}$. Hal ini sesuai dengan penelitian Balia (2005) briket batubara dengan berat $1 \mathrm{~kg}$ lama pembakaran 170 menit dengan kisaran suhu $300-500{ }^{\circ} \mathrm{C}$ sehingga laju pembakarannya adalah 5,88 g/menit. Briket kulit buah kakao memiliki laju pembakaran 4,6 g/menit sampai $6 \mathrm{~g} / \mathrm{menit}$ dengan suhu $400-800^{\circ} \mathrm{C}$. Semakin besar laju pembakaran maka akan mempercepat waktu briket habis terbakar. Biobriket kulit kakao dengan gaya tekan $200 \mathrm{~kg}$ memiliki kadar air yang rendah dan nilai kalor yang tinggi sehingga cepat habis terbakar. Biobriket kulit kakao dengan gaya tekan $100 \mathrm{~kg}$ memiliki kadar air lebih tinggi dibandingkan gaya tekan $200 \mathrm{~kg}$, dan nilai kalor lebih rendah sehingga laju pembakaran lama dari briket gaya tekan $200 \mathrm{~kg}$. Sedangkan biobriket kulit kakao dengan gaya tekan $150 \mathrm{~kg}$ memiliki laju pembakaran lebih lama dari biobriket dengan gaya tekan 100 dan $200 \mathrm{~kg}$, yang disebabkan batas kekuatan mekanik butiran. Kekuatan mekanik butiran merupakan batas kekuatan partikel untuk menahan beban, seperti pada penelitian Poespowati (2009). Subroto dan Sartono (2007) 
menyatakan bahwa penambahan gaya tekan akan memperlambat laju pembakaran dan jika dilakukan penambahan gaya tekan lagi maka laju pembakaran akan mendekati laju pembakaran awal, sehingga dikatakan laju pembakaran lebih lama dan batas kekuatan maksimal butiran terjadi pada tekanan tersebut.

Hasil penelitian mengenai laju pembakaran biobriket sesuai dengan penelitian Poespowati (2009), dalam penelitiannya mengenai briket sampah kota dihasilkan lama pembakaran yang berbeda pada tiap tekanan misalnya gaya tekan $100 \mathrm{~kg}, 150 \mathrm{~kg}$ dan $200 \mathrm{~kg}$ dengan lama pembakaran adalah 195 menit, 250 menit, 185 menit. Gaya tekan $150 \mathrm{~kg}$ merupakan waktu pembakaran yang lebih lama. Penelitian lain yang memperkuat hasil penelitian pengaruh gaya tekan terhadap laju pembakaran adalah Subroto dan Sartono (2007), penelitian tentang briket kokas menyatakan bahwa penambahan gaya tekan $100 \mathrm{~kg}$ menjadi $150 \mathrm{~kg}$, lama pembakaran dari 45 menit menjadi 54 menit dan ketika tekanan ditambah lama pembakaran akan turun menjadi 51 menit dan 41 menit. Gaya tekan optimal briket kokas adalah $150 \mathrm{~kg}$. Penambahan gaya tekan pembriketan akan menaikkan nilai kekuatan mekanik dan memperlambat waktu pembakaran, kenaikkan ini akan mencapai titik maksimal pada gaya tekan 150 kg. Rata-rata temperatur pembakaran briket kokas sekitar $600-700{ }^{\circ} \mathrm{C}$.

\section{F. Nilai Kalor}

Semakin tinggi nilai kalor biobriket arang, semakin baik kualitas biobriket arang yang dihasilkan. Dalam penelitian yang dilakukan oleh Masturin (2002), nilai kalor dipengaruhi oleh kadar air dan kadar abu biobriket. Seamkin tinggi kadar air dan kadar abu biobriket arang, maka semakin akna menurunkan nilai kalor bakar biobriket arang yang dihasilkan.

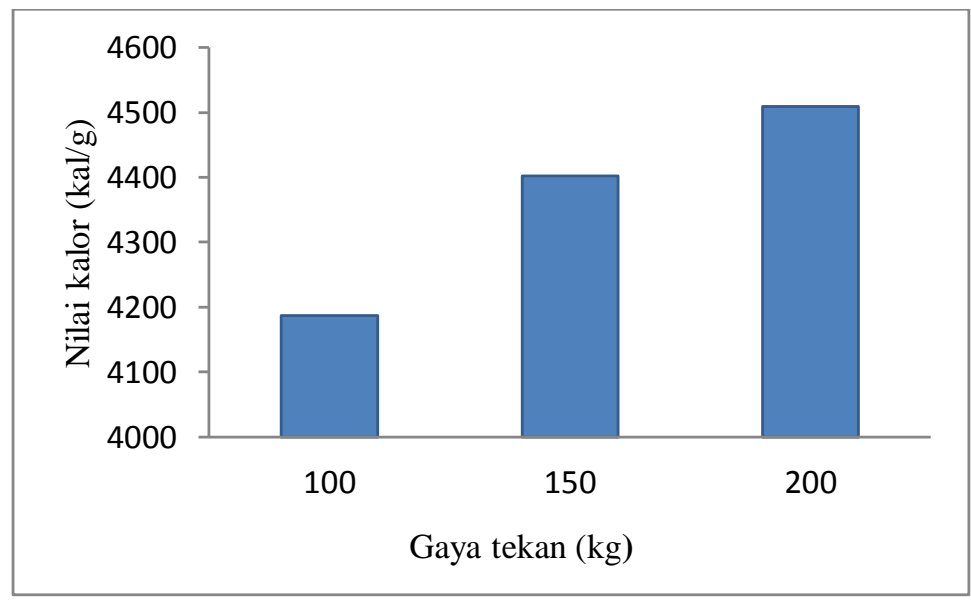

Gambar 6. Pengaruh gaya tekan terhadap nilai kalor biobriket kulit kakao

Hasil pengujian nilai kalor briket kulit buah kakao dengan variasi pembebanan, terlihat semakin tinggi pembebanan, nilai kalorinya juga semakin tinggi. Perbedaan nilai kalori ini cukup jauh berbeda, hal ini disebabkan oleh kadar abu yang ada pada briket. Briket dengan pembebanan tinggi kadar abunya rendah sehingga nilai kalorinya tinggi, sebaliknya untuk briket pembebanan rendah kadar abunya tinggi sehingga nilai kalornya rendah.

Pengujian nilai kalori menunjukkan bahwa briket yang mempunyai nilai kalori tinggi adalah briket dengan pembebanan dengan gaya tekan $200 \mathrm{~kg}$ yaitu sebesar 4509,30 kal/g, sedangkan nilai kalori yang paling rendah adalah briket dengan gaya tekan $100 \mathrm{~kg}$ yaitu sebesar 4187,11 kg/g. Hal ini terjadi karena briket briket gaya tekan $200 \mathrm{~kg}$ memiliki kadar air yang rendah sehingga menghasilkan nilai kalori yang tinggi dan briket gaya tekan $100 \mathrm{~kg}$ memiliki kadar air yang tinggi sehingga menghasilkan nilai kalor yang rendah.

Nilai kalori biobriket kulit kakao yang dihasilkan masih dibawah standar briket (Tabel 1) minimal $5000 \mathrm{kal} / \mathrm{g}$, tetapi nilai kalori yang dihasilkan sesuai dengan penelitian Syamsiro dan Harwin (2007) dengan briket tanpa karbonisasi 4060,82 kal/g, briket batubara 5283,39 kal/g (Balia, 2005) dan briket jerami 3456,48 kal/g (Subroto dan Sartono, 2006). Nilai kalori briket kulit kakao dengan 
karbonisasi cukup tinggi dibandingkan dengan tanpa karbonisasi hal ini terjadi karena briket tanpa karbonisasi mempunyai kadar air tinggi dan memerlukan pemanasan untuk penguapan kadar air tersebut.

\section{G. Efisiensi Briket}

Efisiensi bahan bakar briket diperoleh dengan menggunakan nilai kalori pada masing-masing gaya tekan seperti gaya tekan $100 \mathrm{~kg}$ nilai kalorinya $4187,11 \mathrm{kal} / \mathrm{g}$ gaya tekan $150 \mathrm{~kg}$ nilai kalorinya $4401,63 \mathrm{kal} / \mathrm{g}$ gaya tekan $200 \mathrm{~kg}$ nilai kalorinya 4509,30 kal/g.

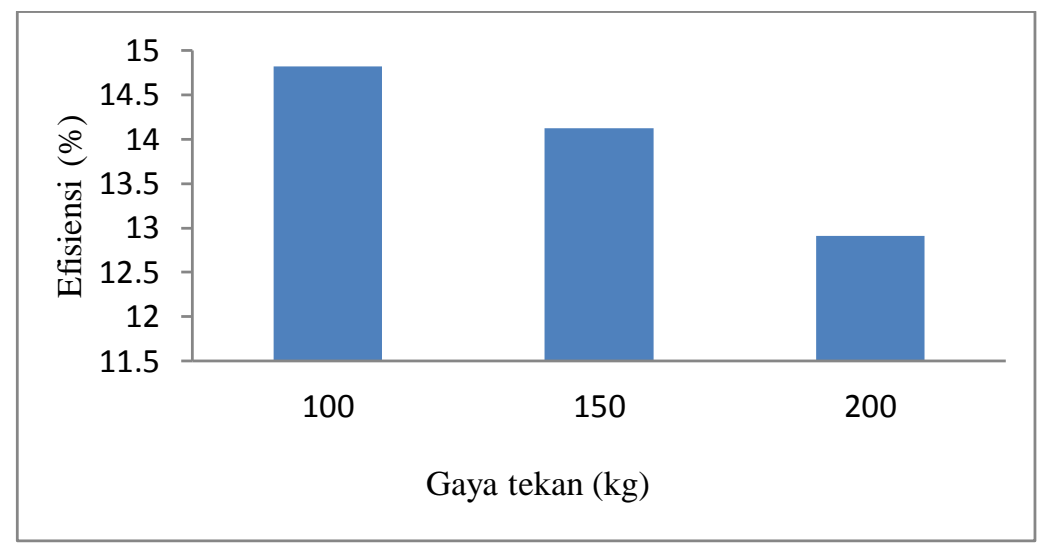

Gambar 7. Pengaruh gaya tekan terhadap efisiensi bahan bakar briket

Efisiensi briket pada gaya tekan $100 \mathrm{~kg}, 150 \mathrm{~kg}$, dan $200 \mathrm{~kg}$ adalah 14,82 \%, 14,12\% dan 12,91 $\%$. Pada umumnya efisiensi briket yang dihasilkan rendah yaitu berkisar antara $12,91 \%$ sampai dengan $14,82 \%$, hal ini terjadi karena briket berbentuk silinder dengan satu lobang ditengah saja sehingga briket membutuhkan waktu yang lama untuk membakar briket itu sendiri, sehingga air yang dididihkan berjumlah sedikit yaitu hanya 6 liter. Jika berbentuk sarang tawon kemungkinan nilai efisiensi bisa lebih tinggi karena briket cepat membakar briket itu sendiri sehingga air yang dididihkan bisa lebih banyak lagi. Briket sarang tawon memiliki bayak lobang pada briket sehingga cepat memanaskan air namun tidak menutup kemungkinan briket cepat habis terbakar.

\section{KESIMPULAN}

kadar air briket setelah dikeringkan selama 24 jam, briket dengan gaya tekan $100 \mathrm{~kg}, 150 \mathrm{~kg}$ dan $200 \mathrm{~kg}$ kadar airnya adalah 14,607 \%, 14,232 \% dan 13,834 \%. Gaya tekan tidak berpengaruh terhadap kadar abu briket dan kadar karbon, yang masing-masing bernilai 27,89\% dan 60,55\%. Densitas briket kulit kakao yang dihasilkan pada gaya tekan $100 \mathrm{~kg}, 150 \mathrm{~kg}$ dan $200 \mathrm{~kg}$ masing-masing yaitu $0,96 \mathrm{~kg} / \mathrm{cm}^{3}, 0,99 \mathrm{~kg} / \mathrm{cm}^{3}$, dan $1,04 \mathrm{~kg} / \mathrm{cm}^{3}$. Laju pembakaran terbesar adalah pada briket dengan gaya tekan $200 \mathrm{~kg}$, sebesar $6 \mathrm{~g} /$ menit. Semakin besar laju pembakaran maka akan mempercepat waktu briket habis terbakar. Biobriket gaya tekan $200 \mathrm{~kg}$ memiliki kadar air yang rendah dan nilai kalor tertinggi sehingga briket cepat habis terbakar. Pada briket gaya tekan $150 \mathrm{~kg}$ memiliki laju pembakaran rendah dari yang lain karena pada gaya tekan tersebut terdapat batas kekuatan maksimal pada butiran. Gaya tekan berpengaruh terhadap nilai kalori pada briket, semakin tinggi gaya tekan nilai kalori semakin meningkat. Densitas $0,96 \mathrm{~kg} / \mathrm{cm}^{3}$ menghasilkan nilai kalori $4187,11 \mathrm{kal} / \mathrm{g}$, densitas 1,044 $\mathrm{kg} / \mathrm{cm}^{3}$ menghasilkan nilai kalori 4509,30 kal/g. Perlakuan gaya tekan dapat memperlihatkan kelebihan pada briket yang diberikan gaya tekan adapun kelebihan briket diberi gaya tekan berbeda diantaranya dapat meningkatkan densitas, nilai kalori briket, menurunkan kadar air.

Penambahan bahan lain untuk pembuatan briket disarankan untuk mengetahui pengaruhnya terhadap laju pembakaran dan karakteristik lain pada briket, misalnya pembuatan briket kulit buah kakao dengan campuran arang batok kelapa. Uji kekuatan mekanik juga disarankan untuk mengetahui kekuatan mekanik pada briket. Pembuatan briket sarang tawon (memiliki banyak lubang) juga disarankan untuk mempermudah proses pengeringan sehingga penurunan kadar air briket sesuai dengan 
SNI dan dapat dibandingkan dengan briket satu lubang ditengah untuk melihat pengaruhnya terhadap efisiensi dan laju pembakaran briket.

\section{DAFTAR PUSTAKA}

Abdullah K, Irwanto AK, Siregar N, Agustina SE, Tambunan AH, Yamin M, Hartulistiyoso E, Purwanto YA, Wulandani D, Nelwan LO. 1998. Energi dan Elektrifikasi Pertanian. Bogor: Proyek Peningkatan Perguruan Tinggi. Institut Pertanian Bogor.

Balia, Lobo. 2005. Batubara sebagai Sumber Energi Utama. (www.tekmira.esdm.go.id). [10 Mei 2009].

Badan Penelitian dan pengambangan Pascapanen peranian (Balitbang). 2008. Energi Mahal, memanfaatkan Briket Arang Sekam.(www.pustakadeptan.go.id). [15 Juni 2017].

Brades, Adi Chandra dan Febrina Setyawati Tobing. 2008. Pembuatan Briket Arang dari Enceng Gondok (Eichornia Crasipess Solm) dengan Sagu sebagai Pengikat. (http://brades.multiply.com). [24 Mei 2017].

Hendra D, Pari G. 2000. Penyempurnaan Teknologi Pengolahan Arang. Laporan Hasil Penelitian Pusat Penelitian dan Pengembangan Hasil Hutan. Bogor: Balai Penelitian dan Pengembangan Kehutan. 2017].

Isroi, 2007. Pemanfaatan Limbah Kulit Buah Kakao. (http://onlinebuku.com). [15 Februari

Kurniawan, Oswan dan Marsono. 2008. Superkarbon, Bahan Bakar Alternatif Pengganti Minyak Tanah dan Gas. Penebar Swadaya. Jakarta.

Masturin A. 2002. Sifat Fisik dan Kimia Briket Arang dari Campuran Kayu, Bambu, Sabut Kelapa, dan Tempurung Kelapa Sebagai Sumber Energi Alternatif. Buletin Penelitian Hasil Hutan 25:242-255.

Meyer MH, Keeping MG. 2000. Review of Research Into the Role of Silicon for Sugarcane Production. Proc. S AfrSug Technol Ass74: 29-40.

Muzakir, MT., Muhammad N., Cut S.Y. 2017. Pemanfaatan kulit Buah Kako Menjadi Briket Arang Menggunakan Kanji Sebagai Perekat. Serambi Engineering. ISSN : 2528-3561. Vol II. No. 3. pp : 124-129.

Poespowati, Tri. 2009. Efisiensi dan Efektivitas Produk Briket Sampah dengan Pengembangan Alat Pressing. (www.pdfqueen.com). [19 Januari 2017].

Subroto, D.A.H dan Sartono. 2007. Pengaruh Variasi Tekanan Pengepresan terhadap Karakteristik Mekanik dan Karakteristik Pembakaran Briket Kokas Lokal. Teknik Mesin Universitas Sebelas Maret Surakarta. Surakarta. (www.eprint.ac.id). [8 Mei 2017]

Syamsiro, M dan Harwin S. 2007. Pembakaran Biomassa Cangkang Kakao : Pengaruh Temperatur Udara Preheat. Jurusan Teknik Mesin Universitas Gadjah Mada. Yogyakarta. (http://digilib.unsri.ac.id). [23 Maret 2017]. 